\title{
Seed Stratification of Engelmann Spruce and Lodgepole Pine: The Effect of Stratification Duration and Timing of Surface-drying
}

by

\author{
Yasuomi Tanaka', N.J. Kleyn ${ }^{2}$ and L.M. Harper ${ }^{3}$
}

\begin{abstract}
Based on the speed and completeness of laboratory germination and nursery bed emergence, the present study showed that for both Engelmann spruce (Picea engelmannii [Parry] Engelmann) and lodgepole pine (Pinus contorta Dougl.): (1) longer stratification generally improved the rate, and in some cases completeness, of germination more so under a cool temperature $\left(15^{\circ} \mathrm{C} / 5^{\circ} \mathrm{C}\right)$ regime than under a warm, standard temperature $\left(30^{\circ} \mathrm{C} / 20^{\circ} \mathrm{C}\right)$ regime emphasizing its importance for early spring outdoor sowing under suboptimal germination temperatures, (2) for a given stratification period, surface-drying at the end of stratification was at least as effective as surface-drying prior to or during stratification, and (3) stratification periods of 6 weeks or longer were generally the most effective. A 6- to 8-week stratification with seeds surface-dried at the end of stratification is recommended for nursery sowing of both species.
\end{abstract}

Key Words: stratification, Pinus contorta, Picea engelmanni, laboratory germination, nursery bed emergence.

\section{Résumé}

La présente étude, basée sur la vitesse et l'état complet de germination en laboratoire et sur l'émergence en pépinière, démontre que pour l'épinette d'Engleman (Pica engelmannii [Parry] Engelmann) et le pin lodgepole (Pinus contorta Dougl.): (1) une stratification plus longue améliore généralement le taux, et dans quelques cas l'état complet de la germination sous un régime de température relativement fraîche $\left(15^{\circ} \mathrm{C} / 5^{\circ} \mathrm{C}\right)$ plutôt qu'une température habituellement chaude de $\left(30^{\circ} \mathrm{C} /\right.$ $20^{\circ} \mathrm{C}$ ) mettant en relief l'importance de la température de stratification pour des ensemencements extérieurs tôts au printemps à des températures sous le niveau optimal requis pour la germination, (2) pour une période donnée de stratification, l'assèchement des surfaces à la fin de la stratification a été au moins aussi efficace que l'assèchement des surfaces avant ou pendant la stratification et (3) des périodes de stratifications de 6 semaines ou plus étaient généralement les plus efficaces. Une stratification de 6 à 8 semaines, les graines ayant leur surface assèchée à la fin de la stratification, est le processus recommandé pour l'ensemencement en pépinière pour les deux espèces.

Mots clés: stratification, Pinus contorta, Picea engelmannii, germination en laboratoire, émergence en pépinière.

\section{Introduction}

Stratification is a commonly used procedure to break dormancy of conifer seed prior to nursery sowing in the Pacific Northwest. Previous work has shown that in a number of species, a longer stratification period resulted in faster and in some cases more complete germination at low temperatures (Allen 1960, Fowler 1959, Tanaka 1976). This relationship indicates the importance of sufficiently long stratification for nursery sowing where germination temperatures are often

Weyerhaeuser Western Forestry Research Center Centralia, Washington 98531 U.S.A.

2Weyerhaeuser Grandview Nursery, Armstrong B.C. Canada VOE 1BO 3Formerly Weyerhaeuser Forestry Research Center. Centralia, Washington 98531 U.S.A. less than optimum. Caution must be exercised, however, since excessively long stratification can result in germination prior to sowing (Allen 1960, Schubert 1955) or deterioration of seed quality (Olson et al. 1959).

In addition to stratification duration, timing of surfacedrying is important. In nursery operations, seeds are surfacedried to facilitate sowing. This is usually done at the end of stratification just prior to sowing. However, seeds may be surface-dried at the beginning of stratification immediately after water soaking, which prevents the spread of fungi during the stratification (Matthews 1981). Seeds can also be surfacedried in the middle of stratification, which not only limits 
germination during stratification but also permits prolonged storage of stratified seeds in the event that unfavorable weather delays sowing (Danielson and Tanaka 1978). Surface-drying in the middle of stratification was found to improve the seed germination of grand fir (Abies grandis [Dougl.] Lindl.), Pacific silver fir (Abies amabilis [Dougl.] Forbes), subalpine fir, (Abies lasiocarpa [Hook] Nutt.) and noble Fir (Abies procera Rehd.) (Edwards 1982a, 1982b, Tanaka 1986).

The present study was undertaken to determine the effect of stratification duration and timing of surface-drying on (1) laboratory germination at two temperature regimes and (2) nursery bed emergence of two commercially important tree species in the interior of British Columbia: Engelmann spruce (Picea engelmanni [Parry] Engelmann) and lodgepole pine (Pinus contorta Dougl.).

\section{Materials and Methods}

This study consisted of a laboratory test and a nursery bed trial. Seed lots 4079 and 2454 of Engelmann spruce were used with germination potentials of $89 \%$ and $73 \%$ respectively. The lodgepole pine seedlots used were 8280 , 8077 and 4267 with germination potentials of $92 \%, 85 \%$ and $64 \%$ respectively.

\section{Laboratory Test}

Ten stratification treatments tested in the laboratory were $0+4,0+8,4+0,6+0,8+0,12+0,4+4,6+4,8+4$ and $12+4$. The numbers in front of the "+" sign are the number of weeks seeds were stratified under "wet" conditions after they were soaked in water for 24 hours and excess water was drained. The numbers after the "+" sign are number of weeks seeds were stratified under "dry" conditions after they were surfacedryed for half an hour.

The 24-hour water soak and surface-drying were done at room temperature $\left(25^{\circ} \mathrm{C} \pm 1^{\circ} \mathrm{C}\right)$. Seeds were stratified at $2^{\circ} \mathrm{C} \pm 1^{\circ} \mathrm{C}$ in plastic bags that were loosely closed with a staple at the top to allow aeration. All treatments were started so that all germination tests could be run at the same time. The moisture content at the conclusion of wet and dry stratification in each treatment was gravimetrically determined. Wet seeds were briefly blotted with a sheet of dry paper towel prior to weighing. Two subsamples of all the treatments consisting of 100 seeds each were oven-dried at $105^{\circ} \mathrm{C}$ for 24 hours. Moisture content of seeds is reported as percentage moisture on a wet weight basis.

After stratification, seeds were placed on water-saturated Kimpak (wadded paper) in plastic boxes, then tested for germination under two temperature regimes. These were (1) a standard, warm regime with alternating temperatures of $30^{\circ} \mathrm{C}$ for 8 hours in the light and then $20^{\circ} \mathrm{C}$ for 16 hours in darkness, as recommended by Association of Official Seed Analysts (1981), and (2) a cool regime with alternating temperatures of $15^{\circ} \mathrm{C}$ for 8 hours in the light and then $5^{\circ} \mathrm{C}$ for 16 hours in darkness to simulate nursery bed conditions in early spring. Two replications, each of 100 seeds, were tested under each temperature regime.

Germination was assessed weekly and counts terminated after 4 and 8 weeks for the standard and cool regimes, respectively. A longer assessment period was chosen under the cool regime because of slower rates of germination. A seed was considered germinated when a radicle reached four times the length of the seed coat. Comparisons were based on (1) speed of germination expressed as the first and fifth week germination respectively at the standard and cool regimes and (2) completeness expressed as total germination (summation of all the germinated seeds) at the end of the test. Both comparisons were made based on the percentages of the total seeds tested. The germination percentage data were analyzed using analyses of variance after arcsin transformation. The treatment differences were tested using the Duncan's new multiple range test (Steel and Torrie 1960). All comparisons were made at a $5 \%$ level of probability.

\section{Nursery Trial}

The seven stratification treatments tested in the nursery trial were $0+4,4+0,6+0,8+0,12+0,4+4$ and $8+4$. Seeds were sown during the first week of May 1983 at the Weyerhaeuser Grandview Nursery located near Vernon, B.C. Half of the trial was covered with plastic mulch Vispore XP5017 to test the feasibility of protecting seeds from wind/sand storms common at this site during the sowing season and to improve nursery bed emergence by elevating bed temperatures.

The field layout for each species followed a split-plot design with four replications. The major plots were plastic mulch and no mulch and subplots were combinations of seed lots and stratification treatments. Each subplot was 0.5 linear meter of nursery bed, 1.2 meter in width with eight double seedling rows. The length of buffer areas between each subplot was $5 \mathrm{~cm}$. Seeds were sown at a density of 217 viable seeds per plot in lodgepole pine and 247 viable seeds per plot in Engelmann spruce.

Comparisons were based on 1) speed of emergence expressed as the fourth week emergence percentage and 2) completeness of emergence expressed as the eighth week emergence percentage. Both comparisons were made based on the total viable seeds tested. The emergence data were analyzed with the same statistical procedure as in the laboratory test.

\section{Results}

\section{Laboratory Test}

The moisture content of the two lots of Engelmann spruce seeds varied from $34 \%$ to $45 \%$ and from $28 \%$ to $41 \%$ at the end of wet and dry stratification, respectively. The moisture content of the three lots of lodgepole pine seeds varied from $38 \%$ to $49 \%$ and from $26 \%$ to $41 \%$ at the end of wet and dry stratification, respectively.

Under the standard temperature regime, the first week germination of both Engelmann spruce lots was generally greater for $6+0,8+0$ and $12+0$ than for the rest of the treatments (Table 1). Total germination did not significantly differ among treatments in most cases.

The $0+4$ and $0+8$ treatments gave the lowest fifth week and total germination in both lots under the cool regime (Table 1). Except for $0+8$, treatments involving a total stratification period of 6 weeks or longer gave greater fifth week and total germination than $0+4$ and $4+0$. Among stratification treatments of 6 weeks or longer, differences were not generally significant, although $12+4$ and $8+4$ gave the highest values in lots 4079 and 2454 respectively in terms of the speed and completeness of germination. 
Table 1. Effect of seed stratification treatments on germination 4 of two Engelmann spruce seed lots at the standard $\left(30^{\circ} \mathrm{C} / 20^{\circ} \mathrm{C}\right)$ and $\mathrm{cool}\left(15^{\circ} \mathrm{C} / 5^{\circ} \mathrm{C}\right)$ temperature regimes in the laboratory.

\begin{tabular}{|c|c|c|c|c|}
\hline \multirow{2}{*}{$\begin{array}{l}\text { Stratification } \\
\text { Treatment }\end{array}$} & \multicolumn{2}{|c|}{ Standard } & \multicolumn{2}{|c|}{ Cool } \\
\hline & 4079 & 2454 & 4079 & 2454 \\
\hline & \multicolumn{2}{|c|}{ First Week } & \multicolumn{2}{|c|}{ Fifth week } \\
\hline $0+4$ & $7 e^{5}$ & if & $19 e$ & $11 \mathrm{c}$ \\
\hline $0+8$ & $4 \mathrm{e}$ & $4 e$ & $14 \mathrm{e}$ & $15 c$ \\
\hline $4+0$ & $34 \mathrm{~cd}$ & $21 \mathrm{bcd}$ & $51 d$ & $22 c$ \\
\hline $6+0$ & $55 \mathrm{abc}$ & $50 a$ & $68 c$ & $56 a b$ \\
\hline $8+0$ & $57 a b$ & $48 a$ & $82 a b$ & $69 a b$ \\
\hline $12+0$ & $69 a$ & $47 a$ & $87 a$ & $70 a b$ \\
\hline $4+4$ & $25 d$ & $14 \mathrm{~cd}$ & $73 \mathrm{bc}$ & $52 b$ \\
\hline $6+4$ & $33 \mathrm{~cd}$ & $12 d$ & $80 a b c$ & $70 a$ \\
\hline $8+4$ & $35 \mathrm{bcd}$ & $25 b$ & $73 \mathrm{bc}$ & $72 a$ \\
\hline \multirow[t]{2}{*}{$12+4$} & $27 d$ & $22 b c$ & $90 a$ & $62 a b$ \\
\hline & \multicolumn{2}{|c|}{ Total } & \multicolumn{2}{|c|}{ Total } \\
\hline $0+4$ & $86 a b$ & $80 a b$ & $23 e$ & $19 c$ \\
\hline $0+8$ & $87 a b$ & $75 a b$ & $32 e$ & $18 \mathrm{c}$ \\
\hline $4+0$ & $81 a b$ & $70 b$ & $60 d$ & $41 b$ \\
\hline $6+0$ & $90 a$ & $89 a$ & $74 c$ & $67 a$ \\
\hline $8+0$ & $83 a b$ & $70 \mathrm{~b}$ & $87 a b$ & $73 a$ \\
\hline $12+0$ & $86 a b$ & $70 b$ & $88 a b$ & $72 a$ \\
\hline $4+4$ & $93 a$ & $70 b$ & $84 a b c$ & $74 a$ \\
\hline $6+4$ & $93 a$ & $81 a b$ & $86 a b$ & $74 a$ \\
\hline $8+4$ & $92 a$ & $69 b$ & $78 \mathrm{bc}$ & $78 a$ \\
\hline $12+4$ & $67 b$ & $76 a b$ & $92 a$ & $72 a$ \\
\hline
\end{tabular}

4All germination values are expressed as percent of total seeds tested.

5 Means followed by the same letters are not significantly $(p<.05)$ different within each column.
In lodgepole pine the trend was the same as in Engelmann spruce. There were large differences in the first week germination, but the total germination did not significantly differ among treatments under the standard regime (Table 2$)$. The first week germination was greater for $4+0,6+0$ and $12+0$ than for $4+4,6+4,8+4$ and $12+4$, which in turn was usually greater than for $0+4$ and $0+8$ in all lots.

Under the cool regime, the fifth week and total germination of all lots of lodgepole pine seeds were significantly less for $0+4$ and $0+8$ compared with the other treatments (Table 2). Total germination was generally higher for seeds stratified for 6 weeks or more and which were surface-dried in the middle of, or at the end of, stratification although among these, no significant effects were observed. For any given total stratification duration, fifth week germination increased as wet (initial) stratification increased.

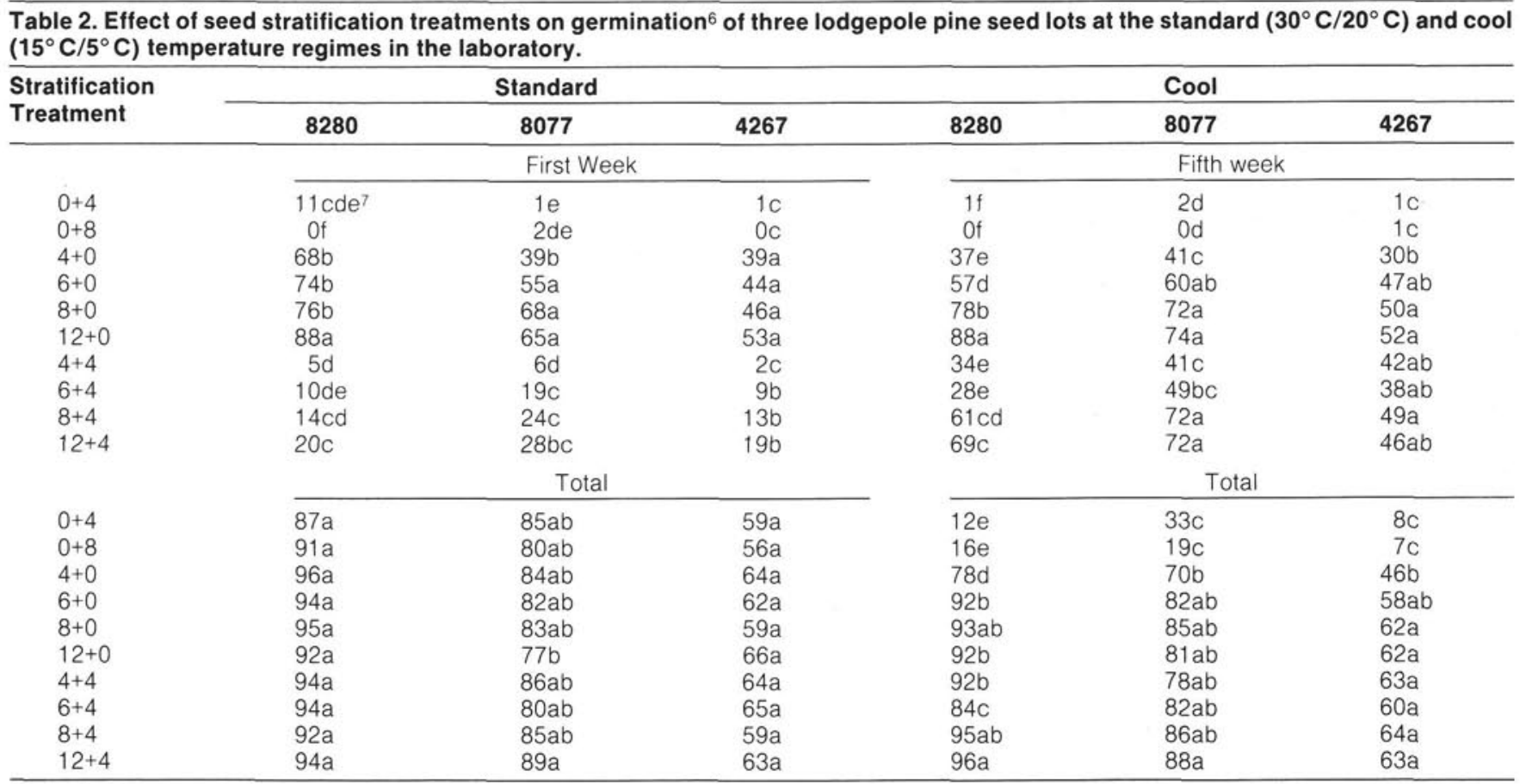

${ }^{6}$ All germination values are expressed as percent of total seeds tested.

7 Means followed by the same letters are not significantly $(p<.05)$ different within each column. 


\section{Nursery Trial}

The plastic mulch used in the present study did not allow adequate penetration of moisture into the nursery bed and had to be removed shortly after it was placed. The analysis of emergence data indicated that the plastic mulch had no significant effect on the speed and completeness of emergence in either species. For this reason, the emergence data of mulched and non-mulched plots were pooled to compare the effect of stratification treatments.

In Engelmann spruce, fourth week and total emergence of lot 4079 were significantly less for $0+4$ than for the rest of the treatments (Table 3). There were no significant differences in fourth week or total emergence among the other treatments which received surface drying in the middle of stratification or at the end of stratification. The $4+0$ treatment tended to give less complete and slower emergence than did the others. In lot 2454 the trend was generally the same, with $0+4$ and $4+0$ being the least effective of all. In this seed lot the fourth week and total emergence of $6+0$ and $8+0$ were higher than the rest of the treatments.

In all lodgepole pine lots, emergence was generally better after $6+0$ or $8+0$ treatments (Table 3 ). The $0+4$ treatment was the least effective in lot 8280 while the 12 -week stratification $(12+0$ and $8+4)$ was generally the least effective in lots 8077 and 4267 .

\section{Discussion}

The results of the laboratory tests in the present study agree with those of other studies (Allen 1960. Fowler 1959 , Tanaka 1976). It showed that longer stratification improved the rate, and in some cases completeness, of germination of Engelmann spruce and lodgepole pine especially under the cool temperature regime emphasizing its importance for early spring outdoor sowing under suboptimal germination temperatures.

In Engelmann spruce, 4-week stratification ( $0+4$ and 4+0) gave a slower speed of germination at the standard regime and also a slower speed of germination and a poorer total germination at the cool regime compared with the other treatments of 6 weeks or longer which were surface-dried at the end of stratification. The results of the nursery trial were in agreement with those of the laboratory tests. Only limited information is available with regard to stratification requirements of Engelmann spruce for nursery sowing. A 3- to 6 -week stratification was reported for this species by Safford (1974). The above results indicate that a slightly longer stratification may be more effective.

There have been contradictory reports with respect to stratification requirements for nursery sowing and field germination of lodgepole pine. Krugman and Jenkinson (1974) recommend a 28-35 day stratification for nursery sowing in the U.S. In Canada, van den Driessche (1969) recommends a 60-day stratification in B.C. while Wang (1978, 1980) recommends a 3-4-week stratification in Alberta. In contrast, Kamra's (1980) and Hocking's (1972) data support the advantage of no stratification in B.C. and Alberta, respectively. The results of the present study were in agreement with the recommendations by Krugman and Jenkinson (1974), van den Driessche (1969), Wang (1978, 1980 ) and Hellum and Wang (1985) showing the benefit of stratification. Stratification periods of 6 weeks or longer and surface-drying at the end of stratification generally gave faster and more complete germination at the standard and cool
Table 3. Effect of seed stratification treatments on the fourth week and total nursery bed emergence ${ }^{8}$ of two Engelmann spruce and three lodgepole pine seed lots.

\begin{tabular}{|c|c|c|c|c|c|}
\hline \multirow{2}{*}{$\begin{array}{l}\text { Stratification } \\
\text { Treatment }\end{array}$} & \multicolumn{2}{|c|}{ Engelmann spruce } & \multicolumn{3}{|c|}{ Lodepole pine } \\
\hline & 4079 & 2454 & 8280 & 8077 & 4267 \\
\hline & \multicolumn{2}{|c|}{ Fourth Week } & \multicolumn{3}{|c|}{ Fourth week } \\
\hline $0+4$ & $34 b^{9}$ & $36 \mathrm{c}$ & $49 b$ & $52 b$ & $61 a b$ \\
\hline $4+0$ & $57 a$ & $51 \mathrm{~b}$ & $71 \mathrm{a}$ & $63 a b$ & $66 a b$ \\
\hline $6+0$ & $66 a$ & $64 a b$ & $81 a$ & $64 a b$ & $71 a$ \\
\hline $8+0$ & $67 a$ & $66 a$ & $74 a$ & $66 a$ & $74 a$ \\
\hline $12+0$ & $66 a$ & $61 a b$ & $82 a$ & $60 a b$ & $62 a b$ \\
\hline $4+4$ & $66 a$ & $61 a b$ & $79 a$ & $61 \mathrm{ab}$ & $67 a b$ \\
\hline \multirow[t]{2}{*}{$8+4$} & $69 a$ & $62 \mathrm{ab}$ & $79 a$ & $56 a b$ & $53 b$ \\
\hline & \multicolumn{2}{|c|}{ Total } & \multicolumn{3}{|c|}{ Totat } \\
\hline $0+4$ & $43 b$ & $44 b$ & $66 b$ & $66 a$ & $76 \mathrm{a}$ \\
\hline $4+0$ & $62 a$ & $59 a$ & $74 a b$ & $67 a$ & $70 \mathrm{ab}$ \\
\hline $6+0$ & $69 a$ & $68 \mathrm{a}$ & $82 a$ & $66 a$ & $73 a b$ \\
\hline $8+0$ & $69 a$ & $70 a$ & $75 a b$ & $68 \mathrm{a}$ & $74 a b$ \\
\hline $12+0$ & $68 a$ & $63 a$ & $82 a$ & $61 a$ & $62 \mathrm{bc}$ \\
\hline $4+4$ & $70 a$ & $61 \mathrm{a}$ & $81 a$ & $62 a$ & $70 a b$ \\
\hline $8+4$ & $71 \mathrm{a}$ & $65 a$ & $81 a$ & $57 a$ & $55 c$ \\
\hline
\end{tabular}

${ }^{8} \mathrm{All}$ emergence values are expressed as percent of total viable seeds tested.

9Means followed by the same letters are not significantly $(p<.05)$ different within each column.

regimes compared with $0+4$ and $4+0$ treatments. The nursery trial showed a similar trend. The performance of unstratified seeds was not investigated in the present study; however, results of additional tests (Tanaka 1984) conducted at the authors' laboratory, not included in this report, showed that unstratified seeds of lodgepole pine (and Engelmann spruce) gave a poorer germination than those stratified with $0+4$ and $0+8$, which were the least effective among the treatments tested in this study

Surface-drying seeds of ponderosa pine (Pinus ponderosa Laws.) to $26 \%$ and Douglas-fir to $37 \%$ in the middle of stratification prevented germination during stratification and prolonged storage capability of stratified seeds (Danielson and Tanaka 1978). Surface-drying stratified true fir seeds to $25 \%$ and $35 \%$ during stratification also prolonged storage capability and improved the speed and completeness of germination (Edwards 1982a, 1982b, and Tanaka 1986).

Our results with Engelmann spruce and lodgepole pine seem to be at variance with the above results. In our study, the moisture content was not controlled to specific levels. Instead, all the wet seeds were surface-dried at $25^{\circ} \mathrm{C}$ for half an hour in the middle of stratification. For a given stratification period, this surface-drying significantly reduced the speed of germination under the standard regime in all cases and under the cool regime in some cases, compared with surface-drying at the end of stratification (ref. $4+4$ vs. $8+0$ and $8+4$ vs. $12+0$ ). The moisture content of surface-dried seeds at the end of the dry stratification period in these treatments $(4+4$ and $8+4)$ ranged from $29 \%$ to $38 \%$ in Engelmann spruce and from $32 \%$ to $39 \%$ in lodgepole pine. These percentages are comparable to or slightly higher than the moisture contents that were reported to be beneficial to ponderosa pine, Douglas-fir and true firs in the previously mentioned studies. 
It is not known from our present data whether the reduced speed of germination is because (1) Engelmann spruce and lodgepole pine in general or particular seed lots used in this study are sensitive to loss of moisture during stratification, or (2) optimum moisture contents for these species lie outside the ranges to which seeds were surface-dried. It is recommended therefore that seeds of these species not be surface-dried in the middle of stratification until further research demonstrates its effectiveness.

Surface-drying before stratification has been recommended to prevent the spread of the cold fungus Caloscrypha fulgens during stratification (Matthews 1981). Van den Driessche (1969) recommends surface-drying lodgepole pine seeds following a 24-hour water soak prior to a 60-day stratification. The result of the present study shows that for a given stratification period, surface drying before stratification significantly reduced the speed of germination under the standard regime and the speed and completeness of germination under the cool regime in both Engelmann spruce and lodgepole pine (Tables 1 and 2) (ref. $0+4$ vs. $4+0$ and $0+8$ vs. $8+0$ ). The speed of emergence and total emergence of both Engelmann spruce lots and one lodgepole pine lot were also reduced by the $0+4$ treatment in the nursery trial. The development of fungus was not visually evident in any of the treatments during stratification in this study probably because of adequate aeration. Based on these observations, surface drying before stratification is not recommended for nursery sowing of these species at this time.

In the nursery, long stratification periods are preferred to prepare seeds for any unusually cold spring. But the delay in sowing time due to unfavorable weather has to be taken into account in determining the optimum stratification regime. Because of this factor a few weeks of leeway should be added to the selected stratification period to avoid an excessive stratification that may adversely affect nursery bed emergence. Based on these considerations a 6- to 8-week stratification with seeds surface-dried at the end of stratification is recommended for nursery sowing of both Engelmann spruce and lodgepole pine.

\section{Acknowledgement}

The authors gratefully acknowledge the following people for their assistance in various phases of this study: C.J. Allison, C.C. Boyd, W.C. Carlson, K. Chisholm, T.G. Daniels, T. Elder, W.T. Gladstone, E. Hutton, M.G. Miller, P.J. Oster, G.A. Ritchie and J.K. Winjum of Weyerhaeuser Company. Special thanks are due to F.M. Tanaka in preparation of the manuscript; to J. Konishi, Silviculture Branch, BC Ministry of Forests, in providing seeds; and to D.G.W. Edwards, Pacific Forest Research Centre, Victoria, C. Leadem, Research Branch, BC Ministry of Forests, and B.S.P. Wang. Petawawa National Forestry Institute, Chalk River, Ontario in review of the manuscript.

\section{References}

Allen G.S. 1960. Factors affecting the viability and germination behavior of coniferous seed. IV. Stratification period and incubation temperature, Pseudotsuga menziesii (Mirb.) Franco. For. Chron. 36: 18-29
Association of Official Seed Analysts. 1981. Rules for testing seeds. J. Seed Technology 6. 162p.

Danielson, H.R. and Y. Tanaka. 1978. Drying and storing stratified ponderosa pine and Douglas-fir seeds. For. Sci. 24:11-16.

Edwards, D.G.W. 1982a. Storage of prechilled Agies seeds. In Proc., IUFRO International Symposium on forest tree seed storage. Petawawa National Forestry Institute, Chalk River, Ontario: 195-203.

Edwards, D.G.W. 1982b. Improving seed germination in Abies. Proc. Int. Plant Propag. Soc. 31: 69-78.

Fowler, D.P. 1959. Rapid germination of white pine seed. For. Chron. 35: 203-211.

Hellum, A.K. and B.S.P. Wang. 1985. Lodgepole pine seed: seed characteristics, handling and use. Proc. Symp. Lodgepole Pine, the Species and its Management. Spokane, Wash. USA and repeated Vancouver, BC. Canada: 187-197.

Hocking, D. 1972. Effects of stratification of Alberta white spruce and lodgepole pine seeds on emergence in operational seed beds. Can. For. Serv., Bi-month. Res. Notes 28: 26-27.

Kamra, S.K. 1980. Studies on Pinus contorta (Doug. ex Loud.) seed germinated at different temperatures. Proc. Pinus contorta as an exotic species. 1980 IUFRO Working Party Meet. on Pinus contorta provenances in Norway and Sweden. Res. Note No. 30, Swedish Univ. Agric. Sci., Dep. For. Genetics, Garpenberg, Sweden. p. 287-289

Krugman, S.L. and J.L. Jenkinson. 1974. Pinus L. In: Seeds of woody plants in the United States. USDA For. Serv., Agric. Handbook No. 450. p. 598-638.

Matthews, R.G. 1981. Contrasting approaches to containerized seedling production. 1. British Columbia. Proc. Canadian Containerized Tree Seedling Symposium. Toronto, Ontario. p. 115-122.

Olson, J.S., F.W. Stearns and H. Nienstaedt. 1959. Eastern hemlock seeds' and seedlings' response to photoperiod and temperature. Conn. Agric. Expt. Sta. Bull. 620. 70p.

Safford, L.O. 1974. Picea A. Dietr. In: Seeds of woody plants in the United States. USDA For. Serv., Agric. Handbook No. 450. p. 587-597.

Schubert, G.H. 1955. Effect of storage temperatures on viability of sugar, Jeffrey and ponderosa pine seed. USDA Forest Serv., Calif. Forest \& Range Expt. Sta. Res. Note 100. 3p.

Steel, R.G.D. and J.H. Torrie. 1960. Principles and Procedures of Statistics. McGraw-Hill Book Co., New York, Toronto, London. $418 p$

Tanaka, Y. 1976. Stratification and other pre-treatments of Douglasfir seed for nursery bed germination. Proc. IUFRO Int. Symp. on Physiology of Seed Germination. Fuji, Japan. p. 163-173.

Tanaka, Y. 1984. Unpublished data. Western Forestry Res. Center, Weyerhaeuser Co., Centralia, Washington.

Tanaka, Y. and D.G.W. Edwards. 1986. An improved and more versatile method for prechilling Abies procera Rehd. seeds. Seed Sci. and Technol. (in press).

Van den Driessche, R. 1969. Forest nursery handbook. BC Dept. Lands, Forests and Water Resour., Forest Serv. Res. Notes No. 48. $44 \mathrm{p}$.

Wang, B.S.P. 1978. Seed yield and germination requirements of Alberta white spruce and lodgepole pine. Alberta For. Dev. Res. Trust Rep. No. 92, 26 p.

Wang, B.S.P. 1980. Germination requirements and effect of seed weight on germination and early seedling development on Alberta lodgepole pine. Alberta Dept. Energy and Nat. Resour., For. Serv. ENR Rep. No. 145, 26 p. 